\title{
Editorial Note: Advances in Multimedia Analysis and Applications for Smart City
}

Published online: 26 November 2018

(C) Springer Science+Business Media, LLC, part of Springer Nature 2018

Multimedia Tools and Applications gratefully acknowledges the editorial work of the scholars listed below on the special issue entitled, "Advances in Multimedia Analysis and Applications for Smart City."

Of 34 papers submitted to this issue, 21 were eventually accepted after a stringent peerreview process.

\section{Zheng Xu (Corresponding Guest Editor)}

The Third Research Institute of the Ministry of Public Security

Shanghai, China

juven_xz@163.com

\section{Prof. Jemal Abawajy}

School of Info Technology, Geelong Waurn Ponds Campus

Deakin University, Australia

jemal.abawajy@deakin.edu.au

\section{Yunhuai Liu}

Peking University, China

yunhuai.liu@gmail.com

Publisher's Note Springer Nature remains neutral with regard to jurisdictional claims in published maps and institutional affiliations. 